\title{
Beköszöntő a Gyermeknevelés Tudományos Folyóirat - hazai csecsemő- és kisgyermeknevelő BA-képzés 10. évfordulóját ünneplő - jubileumi különszámához
}

A csecsemő- és kisgyermeknevelő BA-képzés a pedagógusképzési terület legifjabb tagja.

1999 májusában született meg a csecsemő- és kisgyermeknevelö-gondozó felsőfokú szakképzésnek zöld utat adó MAB-határozat (ez a képzés azóta megszűnt), 2008 októberében pedig a BA-szintű képzés szaklétesítési engedélye látott napvilágot.

Ennek köszönhetően indultak el 2009-ben az ország több tanító- és óvóképző intézményében a BA-szintű oklevéllel záruló képzések.

A BA-képzés megvalósulásával a bölcsődei szakma régi álma vált valóra. Az örömmel párhuzamosan azonban számos megoldandó helyzet is keletkezett természetszerüleg, hiszen a felsőoktatásnak új volt a bölcsődei szakma (a felsőfokú szakképzéshez kapcsolódó néhány éves tapasztalat ellenére is), a bölcsődei szakterületnek pedig a BA-szintű végzettséggel rendelkező kisgyermeknevelők alkalmazása jelentett új kihívást. Az elmúlt évtized a kölcsönös ismerkedés, az egymásra hangolódás jegyében telt, és bár jelentős sikerek születtek ezen a téren, még tennivaló is bőven akad.

A 2019-es adatok szerint (Eurodyce Report, 2019) ${ }^{1}$ az európai országoknak csak egyharmadában kötelező a 0-3 éves korú gyermekeket nevelők számára a BA-szintű vagy annál magasabb iskolai végzettség. Magyarországon a munkakör betöltéséhez a BA-szintü végzettség ma még opcionális, de néhány év múlva várhatóan már reális elvárás, előírás lehet a kisgyermeknevelők számára.

A felsőoktatás keretében zajló képzés egyik jelentős pozitívuma a kora gyermekkori kutatások iránti érdeklődés megélénkülése, helyesebben újbóli felélénkülése ${ }^{2}$.

\footnotetext{
${ }^{1}$ Key Data on Early Childhood Education and Care in Europe, 2019 Edition. Education, Audiovisual and Culture Executive Agency Education and Youth Policy Analysis, Brussels.

2 1998-ban átszervezések következtében a 0-3 éves korú gyermekek intézményes nevelésének szakmai-módszertani
}

Egy tízéves évforduló alkalom az ünneplésre, a visszatekintésre és a jövőbenézésre egyaránt. A Gyermeknevelés jelen tematikus száma is erre vállalkozik. Vendégszerkesztőkként valamennyi képző intézményből vártuk az oktató kollégák alábbi témakörökhöz illeszkedő publikációit:

- a képzés szellemiségét érintő írások, valamint a képzés egészéhez kapcsolódó kutatások, elemzések, fejlesztések bemutatása;

- a 0-3 éves korosztály neveléséhezgondozásához kapcsolódó módszertani kultúra fejlesztését támogató publikációk és

- egy adott képzés bemutatkozása.

A beérkezett 14 publikációt is e témakörök mentén rendeztük el. A közölt írásokat a BAszak létrejöttéről és a 2019. november 14-én és 15-én megrendezett jubileumi konferenciáról készült beszámoló zárja.

A tematikus szám szerzői a felsőoktatási intézmények oktatói, de a megszületett publikációk lektorálásában szerepet vállalt a bölcsődei szakterület több meghatározó szaktekintélye is, név szerint: Bimbó Zoltánné, Csepeliné Faragó-Tóth Gabriella, Keskenyné Péntek Ágnes, Korintus Mihályné dr., Sebestyén Bianka, Rózsa Judit. Igényes és önzetlen munkájukat ezúton is köszönjük!

Reméljük, hogy a tematikus számban megjelenő írásokat haszonnal forgatják a kisgyermekkor iránt érdeklődő kutatók, oktatók, hallgatók egyaránt.

A szerkesztök

fejlesztésével foglalkozó két országos intézet, a Bölcsődék Országos Módszertani Intézete és a Csecsemőotthonok Pikler Emmi Országos Intézete önálló intézetként való működése megszűnt, ennek következtében a korosztály fejlődését, nevelését segítő kutatások mérséklődtek és az új kutatások eredményeinek a szakmai közgondolkodásban való megjelenése esetlegesebbé vált. 